\title{
The Work of Cesare Lombroso and its Reception: Further Contexts and Perspectives
}

Jonathan Dunnage

\section{(2) OpenEdition \\ 1 Journals}

Electronic version

URL: http://journals.openedition.org/chs/2258

DOI: $10.4000 /$ chs.2258

ISSN: 1663-4837

Publisher

Librairie Droz

Printed version

Date of publication: 31 December 2018

Number of pages: 5-8

ISSN: 1422-0857

\section{Electronic reference}

Jonathan Dunnage, "The Work of Cesare Lombroso and its Reception: Further Contexts and

Perspectives", Crime, Histoire \& Sociétés / Crime, History \& Societies [Online], vol. 22, n² | 2018, Online since 02 April 2019, connection on 13 April 2021. URL: http://journals.openedition.org/chs/2258 ; DOI: https://doi.org/10.4000/chs.2258

\section{This text was automatically generated on 13 April 2021}

(C) Droz 


\title{
The Work of Cesare Lombroso and its Reception: Further Contexts and Perspectives
}

\author{
Jonathan Dunnage
}

1 This special issue adds to the ever growing literature on Cesare Lombroso, reflecting a recent flourishing of scholarly interest in the Italian criminal anthropologist. As Paul Knepper and P.J. Ystehede note in the introduction to The Cesare Lombroso Handbook (2013): "A significant body of revisionist scholarship is emerging within criminology and other disciplines across the human sciences. New translations of Lombroso's most widely known works by revisionist pioneers such as Mary Gibson and Nicole Rafter have both fostered and coincided with a re-thinking of his ideas and influence throughout the world [...]". ${ }^{1}$ The articles which follow, three of which originate from a panel on "The influence of Lombroso in policing, judicial and penal environments" organized at the European Social Science History Conference in Valencia (April 2016), relate to and develop a number of key themes and debates, throwing light on hitherto unknown aspects of Lombroso's research, enhancing our understanding of the variety of factors accounting for the manner of reception of his theories, and addressing some of the controversies surrounding his work and its legacy.

2 Critical responses to Lombroso's scientific methodology are well known. Mary Gibson notes that his questionable account of the autopsy on Giuseppe Villella's body, intended as the "dramatic founding event" of criminal anthropology, involved "bending his data to fit preconceived theories". ${ }^{2}$ Lombroso also adopted a succession of flexible and blurred definitions of atavism and the "born criminal" in order to overcome difficulties relating to his original theory. ${ }^{3}$ In this context, Paul Knepper's article "Clocks and Crime: Conceptions of Time in the Writings of Cesare Lombroso" presents an innovative investigation of the criminal anthropologist's work. Knepper explores the shift in Lombroso's thinking from situating criminal behaviour in "deep time" or pre-history to situating crime in the history of lived experience. In this shift, Lombroso departs from 
his role as the first criminologist to pursue scientific knowledge of criminality to that of a historian interested in recovering lost knowledge of human existence.

3 Recent scholarship has also revealed how Lombroso's theories fascinated the general public. Nicole Rafter stresses the visual appeal of criminal anthropology, epitomized in Lombroso's and Ellis's use of photographs and drawings, and in Lombroso's creation of a museum of criminological artefacts: crucially, the images of criminal anthropology "fit perfectly with then-current hierarchies of gender, race, sexuality, social class, and physical ability". ${ }^{4}$ As for the scientific reception of Lombroso's theories in national contexts, this depended on the level of influence already locally enjoyed by criminology and related disciplines, the willingness and ability of established disciplines to welcome or counter his theories, as well as the advantages which his ideas could bring to existing (sometimes opposed) scientific and professional causes. During the 1880s, the French scientific community forged "its own criminological theories out of a thoroughgoing rejection of Lombroso's 'criminal type' and his atavistic conception of criminal aetiology". ${ }^{5}$ In the United States, Lombroso and criminal anthropology made inroads because of lack of professional expertise in social-control work capable of countering them. ${ }^{6}$ In Spain, introductions of the ideas of the Italian School of criminology and of French criminal sociology during the same period (1880s) led to the two becoming combined $;$ conflict between doctors and lawyers in penal matters, and the desire of psychiatrists to gain formal recognition in the legal sphere, also conditioned the reception of Lombroso's criminal anthropology. ${ }^{8}$

With reference to the above context, Silvano Montaldo's article, "Lombroso: the Myth, the History", traces the development of the historiography of Lombroso to the present day, against the broader background of his treatment and representation, in Italy and beyond, by scientific, intellectual and political communities, by the Catholic Church, and by his family descendants. Starting with Lombroso's "unreliable" history of himself, Montaldo illustrates how, until the 1980s, myth, prejudice, ideological bias and professional interests inhibited the achievement of an adequate historical understanding of Lombroso. Anders Pedersson's article "A Science of Nature, a Science of Crime: The Reception and Embedding of Positivist Criminology in Sweden" contributes to our understanding of the factors allowing reception or rejection of Lombroso and criminal anthropology in a particular national context. Drawing on theory concerning how locally-produced knowledge travels and becomes embedded in other local contexts, Pedersson argues that the establishment of positivist criminology in medical and legal spheres first depended on its successful mobilization in popular and political discourses. This is evident in newspaper and popular magazine coverage of international congresses of criminal anthropology, crimes and court trials, but also in contemporary fiction. Although his theories were not fully adopted in Swedish medicine and jurisprudence, Lombroso became a symbol of a new science that would feed into future criminological discourse, as well as becoming a political tool with which progressive forces challenged the conservative Swedish establishment.

5 The impact of the Italian School of criminology in Liberal and fascist Italy is another area of recent focus of research on the history of criminology. Paul Garfinkel has challenged earlier historiography in which scholars have "virtually equated Italian legal culture with positivist criminology, and have identified social-defence principles as the brainchild of Cesare Lombroso and other positivist criminological luminaries". ${ }^{9}$ Garfinkel has also questioned the extent of supporters of positivist criminology in 
Italian state institutions during the first two decades of the twentieth century, apart from the polizia scientifica (scientific police). ${ }^{10}$ Jonathan Dunnage has assessed the influence of Lombrosian criminal anthropology in the Italian police after the Second World War, and has identified in the employment of Lombrosian narratives and rhetoric an attempt to ease Italy's return to the international criminological community following the defeat of fascism. He questions how far, beyond the polizia scientifica, police officers were driven by Lombrosian theories, rather than baser prejudices, in their identification and treatment of "criminals" and "deviants". ${ }^{11}$

Emilia Musumeci's contribution to this issue, "Against the Rising Tide of Crime: Cesare Lombroso and Control of the 'Dangerous Classes' in Italy, 1861-1940", adds to our understanding of the legacy of Lombroso's criminal anthropology in the field of scientific policing in Italy. She examines the techniques and methods employed by police departments from the end of the nineteenth century to the mid-twentieth century to identify and detect criminals and suspects, illustrating how the Italian criminal identification system was inspired by Lombroso's "discovery" of both the biological characteristics of criminals and their external manifestations, as evident in criminal language and tattoos. Musumeci questions the tendency to consider the authoritarian traits in fascist legislation as deriving from Lombroso's theories, arguing that criminal anthropology, rather than influencing the repressive character of the fascist police and the justice system, was distorted by Mussolini's regime for purposes which had not been intended by Lombroso himself and on the basis of principles which Lombroso did not identify with. In this vein, she refutes earlier suggestions that fascist racism derived from racist elements in Lombroso's work, which, she argues, was marginal to Lombrosian criminal anthropology.

The articles making up this special issue illustrate how Lombroso and his legacy continue to be the object of scholarly development and debate. They exemplify growing historical interest in the establishment and reception of Lombroso's theories in different national or local contexts, new investigations into under-studied aspects of Lombroso's work, and the enduring desire to address opposed views and polemics about him. Moreover, the articles should be considered in the context of controversies which have extended beyond or developed outside the academic sphere, not least in the criminologist's native Italy. This is recently evident, for example, in the legal dispute over the "detention" of Villella's skull at the Cesare Lombroso Museum in Turin, settled by the Court of Appeal of Catanzaro in May 2017, and ensuing discussions about the ethical treatment of human remains. ${ }^{12}$

\section{BIBLIOGRAPHY}

Campos, R., Huertas, R., Lombroso but not Lombrosians? Criminal Anthropology in Spain, in Knepper, P., Ystehede, P.J. (Eds.), The Cesare Lombroso Handbook, Abingdon, Routledge, 2013, p. 309-23. 
Ciliberti, R., Monza, F., De Stefano, F., Licata, M., The Trial of the Skull Studied by the Founder of Criminal Anthropology: The War of the Lombroso Museum, Journal of Forensic and Legal Medicine, 2018, 59, [Online] https://doi.org/10.1016/j.jflm.2018.07.011.

Dunnage, J., The Legacy of Cesare Lombroso and Criminal Anthropology in the Post-War Italian Police: A Study of the Culture, Narrative and Memory of a Post-Fascist Institution, Journal of Modern Italian Studies, 2017, 22, 3, p. 365-84.

Garfinkel, P., Criminal Law in Liberal and Fascist Italy, Cambridge, Cambridge University Press, 2016. Gibson, M.S., Cesare Lombroso and Italian Criminology, in Becker, P., Wetzell, R.F. (Eds.), Criminals and Their Scientists: The History of Criminology in International Perspective, Cambridge, Cambridge University Press, 2006, p. 137-158.

Knepper, P., Ystehede, P.J., Introduction, in Knepper, P., Ystehede, P.J. (Eds.), The Cesare Lombroso Handbook, Abingdon, Routledge, 2013, p. 1-7.

Lombroso, C., Criminal Man, Durham, NC, Duke University Press, 2006 [trans. by Gibson, M., Rafter, N.H.].

Lombroso, C., Ferrero, G., Criminal Woman, the Prostitute and the Normal Woman, Durham, NC, Duke University Press, 2004 [trans. by Gibson, M., Rafter, N.H.].

Rafter, N.H., Criminal Anthropology. Its Reception in the United States and the Nature of Its Appeal, in Becker, P., Wetzell, R.F. (Eds.), Criminals and Their Scientists: The History of Criminology in International Perspective, Cambridge, Cambridge University Press, 2006, p. 159-181.

Renneville, M., Lombroso in France. A Paradoxical Reception, in Knepper, P., Ystehede, P.J. (Eds.), The Cesare Lombroso Handbook, Abingdon, Routledge, 2013, p. 281-92.

\section{NOTES}

1. Knepper, Ystehede (2013, p.5). For recent translations of Lombroso, see Lombroso (2006); Lombroso, Ferrero (2004).

2. Gibson (2006, p. 139).

3. Gibson (2006, p. 143-147).

4. Rafter (2006, p. 171 and 177).

5. Renneville (2013, p. 282-283).

6. Rafter (2006, p. 168).

7. Campos, Huertas (2013, p. 310).

8. Campos, Huertas (2013, p. 312-314).

9. Garfinkel (2016, p. 8).

10. Garfinkel (2016, p. 350-351).

11. Dunnage (2017).

12. Ciliberti et al. (2018). 


\section{AUTHOR}

\section{JONATHAN DUNNAGE}

Department of History, College of Arts and Humanities

Swansea University, UK

j.dunnage[at]swansea.ac.uk 